\title{
Adiantum (Pteridaceae) no Arboreto do Jardim Botânico do Rio de JANEIro, BrasiL ${ }^{1}$
}

\author{
Sara Lopes de Sousa Winter ${ }^{2}$, Claudine Massi Mynssen ${ }^{3}$ \& Jefferson Prado ${ }^{4}$
}

\begin{abstract}
Resumo
(Adiantum no arboreto do Jardim Botânico do Rio de Janeiro, Brasil) Apresenta-se o estudo das espécies do gênero Adiantum que ocorrem espontaneamente ou são cultivadas no Jardim Botânico do Rio de Janeiro. Foram encontradas 13 espécies e um cultivar. Verificou-se que 12 espécies são nativas do neotrópico, sendo uma endêmica do Brasil (Adiantum pentadactylon) e duas espécies são provenientes do Paleotrópico (A. caudatum e A. formosum). São apresentadas chave de identificação, descrições, ilustrações e comentários sobre as espécies estudadas.
\end{abstract}

Palavras-chave: flora, taxonomia, Pteridophyta, Adiantaceae, identificação.

\section{Abstract}

(Adiantum in the arboretum of the Rio de Janeiro Botanical Garden, Brazil) This work presents the survey of the genus Adiantum of the Rio de Janeiro Botanical Garden. Thirteen species of the genus Adiantum and one cultivar were found. Twelve species are widely distributed in the Neotropic, one species is endemic of Brazil (Adiantum pentadactylon), and two species are native from the Paleotropic (A. caudatum, A. formosum). Keys, descriptions, illustrations and comments of the studied species are presented.

Key words: flora, taxonomy, Pteridophyta, Adiantaceae, identification.

\section{INTRODUÇÃO}

Pteridaceae é uma família constituída por plantas terrestres, rupícolas, saxícolas ou aquáticas. Apresenta caule reptante, ereto a decumbente, provido de escamas ou tricomas; frondes monomorfas ou dimorfas; pecíolo contínuo com caule; lâmina inteira ou decomposta, glabra ou com tricomas, escamas, ou com indumento farináceo; nervuras livres ou anastomosadas. Soros ao longo das nervuras e sem indúsio, soros marginais ao longo de uma comissura vascular, protegidos pela margem da lâmina revoluta $\mathrm{e}$ modificada, ou ainda, soros acrosticóides; esporos triletes, aclorofilados (Tryon \& Tryon 1982).

A família possui uma ampla distribuição geográfica com cerca de 35 gêneros, dos quais 22 ocorrem nas Américas (Tryon \& Tryon 1982). Segundo Prado (2004), a caracterização morfológica desta família é dificultada considerando que as atuais circunscrições não refletem a filogenia do grupo.
Segundo o conceito de Tryon \& Kramer (1990), Pteridaceae divide-se em seis subfamílias: Taenitidoideae, Platyzomatoideae, Cheilanthoideae, Ceratopteridoideae, Adiantoideae e Pteridoideae. A subfamília Adiantoideae está representada por um único gênero Adiantum L. e é caracterizada por possuir soros arredondados a alongados, localizados na margem dos segmentos reflexos sendo fortemente modificada com nervuras presentes.

O arboreto do Jardim Botânico do Rio de Janeiro foi fundado por d. João VI, com o objetivo de cultivar e introduzir no Brasil espécies de todo o mundo que possuíssem alto valor comercial, principalmente as especiarias do Oriente. No arboreto algumas espécies estão dispostas em áreas que representam seus ecossistemas de origem, outras são cultivadas em estufas ou organizadas por coleções (Alfaia et al. 1998).

O objetivo deste trabalho é apresentar o levantamento das espécies espontâneas ou

\footnotetext{
Artigo recebido em 10/2006. Aceito para publicação em 03/2007.

${ }^{1}$ Monografia de Bacharelado da primeira autora.

${ }^{2}$ Bacharel em Ciências Biológicas, Universidade Santa Úrsula, Bolsista PIBIC/CNPq, Instituto de Pesquisa Jardim Botânico do Rio de Janeiro. swpteridos@yahoo.com.br

${ }^{3}$ Instituto de Pesquisa Jardim Botânico do Rio de Janeiro. Rua Pacheco Leão 915, 22460-030, Rio de Janeiro, RJ, Brasil. ${ }^{4}$ Instituto de Botânica. C.P. 3005, 01061-970. São Paulo, SP, Brasil.
} 
cultivadas do gênero Adiantum ocorrentes no arboreto do Jardim Botânico do Rio de Janeiro e fornecer subsídios para identificação das mesmas.

\section{Material e Métodos}

O arboreto do Jardim Botânico do Rio de Janeiro (JBRJ) está situado no município do Rio de Janeiro e ocupa uma área de 54 hectares, que estão divididos em 122 aléias, 40 seções, 194 canteiros, seis estufas e viveiros, abrigando cerca de 8.200 espécies de plantas vasculares, entre representantes da flora nativa e espécies exóticas aclimatadas (Alfaia et al. 1998). Trata-se de uma área contínua com um remanescente de Mata Atlântica limitando-se com o Parque Nacional da Tijuca.

Os espécimes foram coletados em todo o arboreto do JBRJ durante um ano e foram registrados dados relativos ao hábitat, tipo de substrato, umidade e exposição à luz. O material foi herborizado segundo técnicas usuais para plantas vasculares (Windisch 1992) e todos os espécimes foram incorporados no Herbário do Jardim Botânico do Rio de Janeiro (RB), com o envio de duplicatas para o Herbário do Instituto de Botânica (SP).

O material foi identificado a partir da bibliografia específica para o gênero, Scamman (1960), Tryon \& Tryon (1982), Mickel \& Beitel (1988), Proctor (1989), Prado \& Palacios-Rios (1998), Prado (2000), Lellinger \& Prado (2001), Prado (2001), Lellinger (2002), Prado \& Lellinger (2002), Prado \& Smith (2002), Prado (2003), Prado (2004), Smith \& Prado (2004), e a partir de comparações feitas com espécimes depositados no acervo do Herbário de Jardim Botânico do Rio de Janeiro e do Herbário do Instituto de Botânica.

A abreviatura dos nomes dos autores das espécies seguiu Pichi-Sermolli (1996). A análise da distribuição geográfica das espécies baseou-se na bibliografia consultada e no levantamento de herbário, adotando-se os padrões de distribuição propostos por Lellinger (2002).

As descrições dos táxons foram feitas a partir do exame dos espécimes coletados no arboreto e do material depositado no acervo do Herbário RB e segue os termos propostos por Lellinger (2002), com algumas modificações.

\section{Resultados}

As espécies do gênero Adiantum podem ocorrer como terrestre ou rupícola. $\mathrm{O}$ gênero caracteriza-se por apresentar caule reptante ou subereto, escamoso; frondes monomorfas; pecíolo castanho a preto, brilhante e glabro a densamente coberto por escamas ou tricomas; lâmina simples a 5-pinada; segmentos freqüentemente romboidais, trapezoidais ou flabelados, dimidiados ou não, sésseis ou curtamente peciolulados, articulados ou não à raque, glabro ou com tricomas; nervuras livres ou anastomosadas. Soros reniformes, oblongos ou lineares, um a muitos por segmento, recobertos por um falso indúsio, que é formado pela margem revoluta da lâmina; esporos triletes, tetraédrico-globosos.

Segundo Lellinger \& Prado (2001), Adiantum é um gênero grande e amplamente distribuído, com aproximadamente 200 espécies nos trópicos, com cerca de 70 espécies ocorrendo na América do Sul. No Brasil, estima-se que ocorram 63 espécies, o que corresponde a $90 \%$ do total que se conhece para o continente americano. De acordo Mickel \& Beitel (1988), a maioria das espécies é terrestre, ocorre em florestas, em locais sombreados e banco de rochas e preferem, muitas vezes, locais úmidos.

\section{Chave para as espécies de Adiantum do arboreto do JBRJ}

1. Caule ereto, raque prolífera.

2. Pinas não articuladas com a raque

1. A. caudatum

2'. Pinas articuladas com a raque

2. A. deflectens

1'. Caule reptante, raque não prolífera. 
3. Lâmina 2-pinada.

4. Raque com escamas e tricomas

3. A. serratodentatum

4'. Raque apenas com escamas.

5. Lâmina com 2 pares de pinas, pínulas dimidiadas à subdimidiadas .... 4. A. latifolium

5'. Lâmina com mais de 2 pares pinas, pínulas com outra conformação.

6. Escamas da raque adaxialmente lanceoladas, com 3-4 células de largura, margens ciliadas 5. A. diogoanum

6'. Escamas da raque adaxialmente filiformes, com 1-2 células de largura, margens inteiras

6. A tetraphyllum

3'. Lâmina mais vezes decomposta.

7. Raque com escamas e/ou tricomas.

8. Raque e raquíola flexuosas, com tricomas articulados

7. A. formosum

8'. Raque e raquíola não flexuosas, com tricomas articulados e escamas .... 8. A. pectinatum

7'. Raque glabra.

9. Pínulas não articuladas com o peciólulo.

10. Indúsio oblongo

9. A. pentadactylon

10'. Indúsio reniforme

10. A. raddianun

9'. Pínulas articuladas com o peciólulo.

11. Raque cilíndrica abaxialmente e sulcada adaxialmente.

12. Pínulas auriculadas, com aurícula voltada para a raquíola ...... 11. A. anceps

12'. Pínulas trapeziformes, sem aurícula.

12. A. trapeziforme

11'. Raque cilíndrica.

13. Pínula cuneado-flabelada

13. A. tenerum

13'. Pínula deltóide-flabelada

14. A. tenerum cv. fergunsoni

1. Adiantum caudatum L., Sp. pl. 2: 1094. 1753. Fig. 1c

Plantas terrestres. Caule ereto, 2,5-2,8 mm diâm., revestidos por escamas lanceoladas, ápice afilado a acuminado, margens crenadas, $5-7,5 \times 0,5 \mathrm{~mm}$. Frondes decumbentes; pecíolo 2-7 cm $\times 0,5-1,5 \mathrm{~mm}$, cilíndrico, castanho-claro a castanho-escuro, revestido por escamas semelhantes às do caule principalmente na base e distalmente por tricomas articulados, castanho-claros com ca. $1 \mathrm{~mm}$ compr.; lâmina 1-pinada, linear, 39-43 × 3-4,5 cm, cartácea, verde-escura com idioblastos em ambas as faces; raque cilíndrica, sulcada na face adaxial, castanho-escura a nigrescente ou às vezes avermelhada, revestida por tricomas articulados semelhante aos do caule, prolifera no ápice; pinas 28-46 pares, dimidiadas, curto-pecioluladas, não articuladas com a raque, alternas, ápice redondo, base truncada e paralela ou em ângulo agudo com a raque, lado acroscópico incisolobado, margens estéreis denteadas; venação livre, nervuras furcadas, glabras. Soros marginais, $2-3(3,5) \times 0,5-2 \mathrm{~mm}, 2-6$ por pina; indúsios oblongos, membranáceos.

Material examinado: estufa do Orquidário, 19.VIII.2003, S. L. S. Winter 79 (RB); 12.V.2004, S. L. S. Winter 94, 100 (RB); 17.VIII.2004, S. L. S. Winter 175 (RB); 15.V.2005, S. L. S. Winter 235 (RB).

Esta espécie apresenta distribuição Paleotropical, ocorrendo na Malásia, Filipinas e Indonésia. Ocorre na estufa do Orquidário, em local sombreado e bastante úmido, próximo ao córrego.

2. Adiantum deflectens Mart., Ic. cr. Bras: 94. 1834.

Fig. $1 \mathrm{a}-\mathrm{b}$

Plantas terrestres. Caule ereto, 1,5-3 mm diâm., com escamas linear-lanceoladas, ápice agudo, margens inteiras, $2-3 \times 1-1,3 \mathrm{~mm}$. Frondes eretas a decumbentes; pecíolo $7-11 \mathrm{~cm}$ $\times 0,5-1 \mathrm{~mm}$, cilíndrico, castanho-escuro, revestido na base por escamas semelhantes às do caule; lâmina 1-pinada, oblonga, 9-17× 


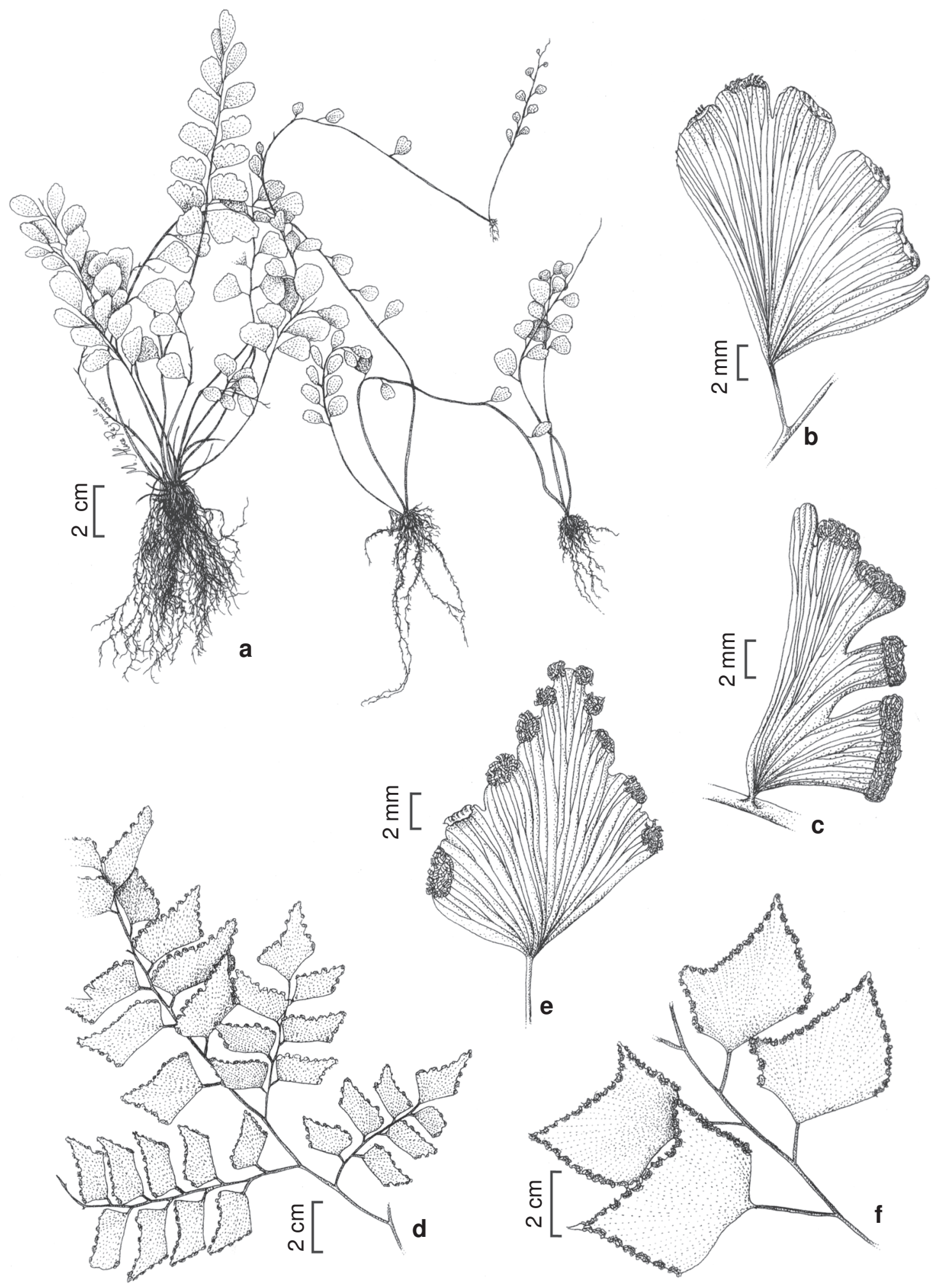

Figura 1 -a-b. Adiantum deflectens Mart. - a. hábito (Winter 82); b. pínula fértil (Winter 20). c. A. caudatum L. -c. pínula fértil (Winter 175). d-e. A. trapeziforme L. - d. pina; e. pínula (Simões 77). f. A. anceps Maxon \& C.V. Morton - f. pina (Winter 90). 
2,5-3,5 cm, cartácea, verde-clara, ápice agudo, base cuneada, com idioblastos em ambas as faces; raque cilíndrica, castanho-escura, glabra, prolifera no ápice; pinas 5-7 pares, pecioluladas, flabeladas ou dimidiadas, ápice redondo, base cuneada, margens incisoserreada; venação livre, nervuras furcadas, terminando nos dentes na margem da lâmina, glabras, articuladas com a raque. Soros marginais, $1-3 \times 0,5 \mathrm{~mm}, 2-6$ por pínula; indúsio oblongo, membranáceo.

Material examinado: estufa do Orquidário, 11.V.1989, L. S. Sylvestre s.n. (RB 403110); 17.V.2004, S. L. S. Winter 82 (RB).

Trata-se de uma espécie nativa e com ampla distribuição na América tropical. No território brasileiro ocorre nos estados de Rondônia a São Paulo. Foi coletada na estufa do Orquidário, à sombra de outras plantas e em local bastante úmido. De acordo com Prado (2005) esta espécie é amplamente cultivada na Europa.

3. Adiantum serratodentatum Willd., Sp. pl. 5: 445. 1810.

Fig. 2 h-i

Plantas terrestres. Caule curto-reptante, ca. $2 \mathrm{~mm}$ diâm., com escamas filiformes a lanceoladas, castanho-claras, ápice acuminado, margens inteiras, $1,5-2 \times 0,2-1,5 \mathrm{~mm}$. Frondes eretas; pecíolo ca. $11 \mathrm{~cm} \times 1,5 \mathrm{~mm}$, anguloso, sulcado adaxialmente, castanho-escuro a preto, revestido por escamas filiformes, pectinadas, castanho-claras, 1-3 mm compr. e tricomas articulados; lâmina 2-pinada, ca. 16 $\times 13 \mathrm{~cm}$, cartácea a subcoriácea, verde-escura; raque angulosa, sulcada adaxialmente, castanho-escura a preta, revestida de escamas filiformes, pectinadas, castanho-claras 1,8-2 mm compr. e tricomas articulados, idioblastos presentes; pina 3-4 pares, pecioluladas, lanceoladas; pina apical conforme; pínulas dimidiadas, ápice arredondado, base cuneada, margens serreadas, com escamas semelhantes às da raque na face abaxial, não articuladas ao peciólulo; venação livre, nervuras simples ou furcadas. Soros marginais, 0,9-1,5 ×0,40,5, 3-4 por pínula; indúsio oblongo, membranáceo.
Material examinado: canteiro 15A, 2.VI.2004, S. L. S. Winter 116 (RB).

Material adicional: BRASIL. RIO DE JANEIRO: Maricá, Inoã, 15.IV.2004, S. L. S. Winter. 38 (RB).

Trata-se de uma espécie com ocorrência ampla na América tropical, sendo encontrada desde a costa Rica até Brasil. No Brasil ocorre nos estados de Roraima a Santa Catarina

No arboreto ocorre ao longo de canteiros, em terrenos secos e expostos ao sol ou em locais sombreados.

4. Adiantum latifolium Lam., Encycl. 1: 43. 1783.

Fig. $2 \mathrm{~g}$

Plantas terrestres. Caule longo-reptante, 3-6 mm diâm., com escamas lanceoladas, castanho-escuras, ápice agudo, margens inteiras a esparsamente denticuladas, $2-5 \times$ 0,5-1,5 mm. Frondes eretas; pecíolo 20,5$35 \mathrm{~cm} \times 2-3 \mathrm{~mm}$, quadrangular e sulcado adaxialmente, castanho-escuro a preto, revestido por escamas semelhantes às do caule e escamas filiformes com a base ciliada, castanhas, ápice agudo, margens inteiras a ciliadas; lâmina 2-pinada, 17-36×18-24 cm, cartácea, verde-escura, com idioblastos na face adaxial; raque quadrangular e sulcada adaxialmente, castanho-escura a preta, revestida por escamas semelhantes às do pecíolo; pinas 2 pares, pecioluladas, ápice agudo, pina apical conforme; pínulas dimidiadas a subdimidiadas, não articuladas com o peciólulo, ápice agudo, base cuneada, margens serreadas, face abaxial glauca, glabras em ambas as faces; venação livre, nervuras simples ou furcadas. Soros marginais, $2-4 \times$ 0,5-1,1 mm, 10-19 por pínula; indúsio oblongo, membranáceo.

Material examinado: canteiro 14 B, 13.II.2003, F.R. Simões et al. 1 (RB); 21.VII.2003, S. L. S. Winter et al. 63 (RB); canteiro 5A, 12.V.2003, F. R. Simões et al. 36 (RB); canteiro 14A, 17.V.2004, S. L. S. Winter 84 (RB).

É uma espécie nativa na América tropical e amplamente distribuída. No Brasil, ocorre de Roraima a Santa Catarina. Pode ser encontrada na estufa do Orquidário, como semiciófila, também em muitos canteiros à sombra, principalmente em locais próximos às raízes de palmeiras. 
5. Adiantum diogoanum Glaz. ex Baker, London J. Bot. Brit. \& For. 20: 310. 1882.

Fig. 2 d-f

Plantas terrestres. Caule longo-reptante, 2-3 mm diâm., revestidos por escamas linearlanceoladas, castanho-escuras, ápice acuminadoagudo, margens ciliadas, 0,5-1,5×0,1-0,4 mm. Frondes eretas; pecíolos 19-48 cm $\times 2-3 \mathrm{~mm}$, cilíndricos a angulosos, sulcados adaxialmente, castanho-escuros a preto, revestidos por escamas lanceoladas com 3-4 células de largura, com margens e base ciliadas, castanho-claras, ápice acuminado-agudo, 0,5-1 mm compr. e tricomas articulados; lâmina 2-pinada, deltóide, 25-38 × 22-30 cm, cartácea, verde-clara, com idioblastos em ambas as faces; raque cilíndrica a angulosa, sulcada adaxialmente, castanho-escura a preta, revestida por escamas semelhantes às do pecíolo em ambos os lados; pinas 4-5 pares, pecioluladas, oblongas com ápice acuminado; pina apical conforme; pínulas trapeziformes falcadas, par proximal flabeliformes, ápice agudo e voltado para o ápice da lâmina, base cuneada, margens serreadas, escamas com base ramificada; venação livre, nervuras simples ou furcadas. Soros marginais, $2-5 \times 0,5-1 \mathrm{~mm}, 1-6$ por pínula; indúsio oblongo, membranáceo.

Material examinado: estufa do Orquidário, 12.V.2004, S. L. S. Winter 88 (RB).

Material adicional: BRASIL. GOIÁS: Nova América, 16.III.1978, J. C. Guimarães 19 (RB); Goiania, 16.XII.1936, A. C. Brade 15357 (RB).

Espécie endêmica do Brasil ocorrendo nos estados de Pernambuco, Alagoas, Minas Gerais, Rio de Janeiro, São Paulo e Paraná. Ocorre na estufa do Orquidário, sendo cultivada em locais sombreados e úmidos.

\section{Adiantum tetraphyllum Willd., Sp. pl. 5:} 441. 1810.

Fig. 2 a-c

Plantas terrestres. Caule longo-reptante, 2,5-4 mm diâm., revestidos por escamas linearlanceoladas, castanho-avermelhadas, ápice acuminado-agudo, margens denteadas, 1,5-2,5 $\times 0,2-0,5 \mathrm{~mm}$. Frondes eretas; pecíolos 30$49 \mathrm{~cm} \times 2-3 \mathrm{~mm}$, cilíndrico a anguloso, sulcado adaxialmente, castanho-escuro a preto, revestido por escamas filiformes com 1-2 células de largura, com base ramificada, castanho-claras a avermelhada, ápice acuminado-agudo, margem inteira, 1,5-2,5 $\times$ 0,1-0,2 mm larg; lâmina 2-pinada, deltóide, 28-37×24-31 cm, cartácea, verde-clara, com idioblastos em ambas as faces; raque cilíndrica a angulosa, sulcada adaxialmente, castanho-escura a preta, revestida adaxialmente por escamas semelhantes às do pecíolo, abaxialmente por escamas lanceoladas; pinas 4-5 pares, pecioluladas, oblongas; pina apical conforme; pínulas trapeziforme-dimidiadas, ápice longo acuminado e voltado para o ápice da lâmina, base cuneada, margens denteada, face abaxial com tricomas esparsos; venação livre, nervuras simples ou furcadas. Soros marginais, $2-5 \times 0,5-1 \mathrm{~mm}$, 4-13 por pínula; indúsio oblongo, membranáceo. Material examinado: estufa do Orquidário, 12. II.2005, S. L.S. Winter 256 (RB)

Material adicional: Horto Florestal, 15.IV.1994, C. M. Mynssen et al. 89 (RB). 7.IV.1993, R. Marquete et al. 791 (RB); 8.XI.1994, P. Botelho et al. 24 (RB).

Espécie amplamente distribuída na América tropical, ocorrendo desde o sul do México até o Paraguai. No Brasil, é encontrada nos estados do Pará, Mato Grosso, Mato Grosso do Sul, Goiás, Distrito Federal, Bahia, Rio de Janeiro, São Paulo e Paraná. Ocorre na estufa do Orquidário, sendo cultivada em locais sombreados e úmidos.

7. Adiantum formosum R. Br., Prodr.: 155. 1810.

Fig. 3 a-d

Plantas terrestres. Caule curto-reptante, 0,5-1 mm diâm., revestido por escamas lanceoladas, castanho-claras, ápice agudo, margem denteada 1,9-3,3×0,5-1 mm. Frondes eretas a decumbentes; pecíolo $17-30 \mathrm{~cm} \times 2$ $5 \mathrm{~mm}$, cilíndrico, castanho-escuro, revestido na base por escamas semelhantes às do caule, superfície com pequenas projeções, glabro na face adaxial e com tricomas castanhoavermelhados, articulados na face abaxial, tricomas ca. $1 \mathrm{~mm}$ compr.; lâmina 3-pinada, deltóide, $21-49 \times 25-30 \mathrm{~cm}$, cartácea, verdeescura, sem idioblastos; raque e raquíola flexuosas, cilíndricas, castanho-escuras, com tricomas articulados, castanho-avermelhados na face abaxial, 1-1,4 mm compr.; pinas 5-7 


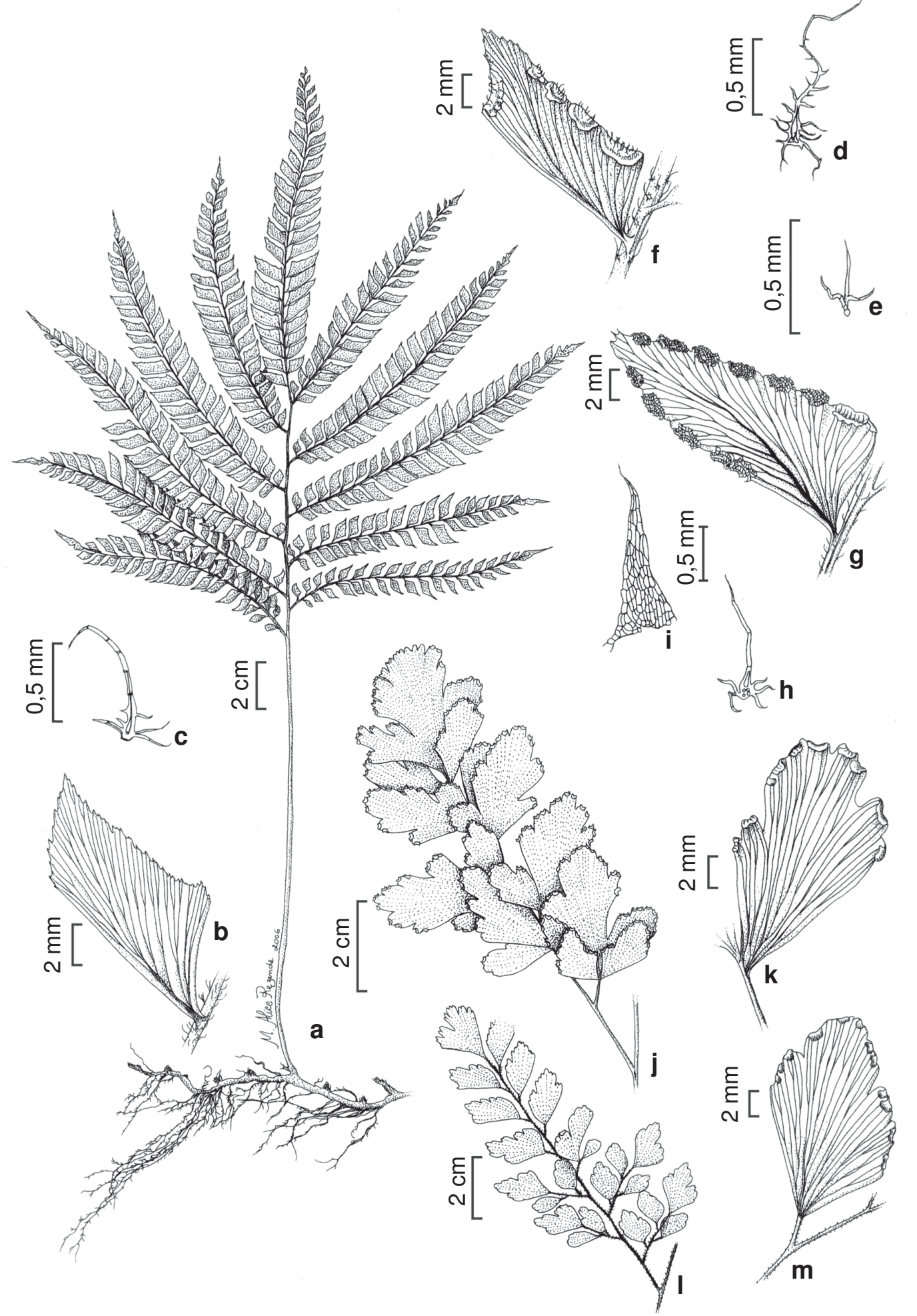

Figura 2 - a-c - Adiantum tetraphyllum Humb. \& Bonpl. ex Willd. - a. hábito; b. pínula; c. escama do pecíolo (Winter 242). d-f-A. diogoanum Glaz. ex Baker-d. escama da lâmina; e. tricoma do pecíolo; f. pínula (Winter 88). g-A. latifolium Lam. - g. pínula (Simões 36). h-i - A. serratodentatum Humb. \& Bonpl. ex Willd. - h. escama do pecíolo; i. parte da escama do rizoma (Winter 116). j-k - A. tenerum cv. fergunsonii - j. pina; i. pínula (Sylvestre 403114). 1-m - A. tenerum Humb. \& Bonpl. ex Willd. - 1. pina; m. pínula (Sylvestre 403111). 


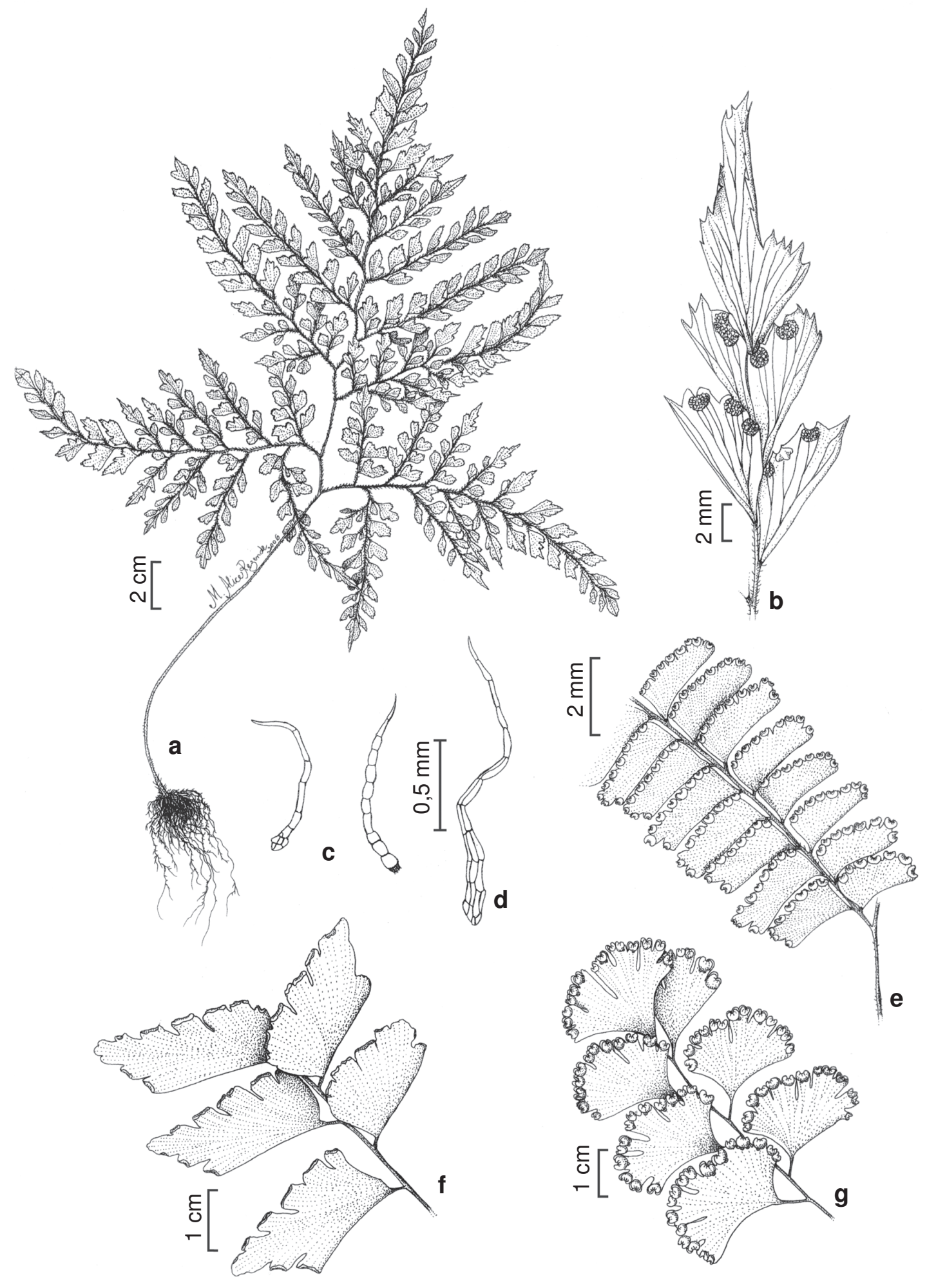

Figura 3 - a-d. Adiantum formosum $\mathrm{R} . \mathrm{Br}$ - a. hábito (Winter 81); b. pina; c. tricoma da raque; d. escama e tricoma do pecíolo (Winter 93). e. A. pectinatum Kunze ex Baker - e. pina (Simões 78). f. A. pentadactylon Langsd. \& Fisch. - f. pina (Simões 90). g. A. raddianum C.Presl - g. pina (Simões 93). 
pares, pecioluladas; pina apical conforme; pínulas flabeladas a trapeziformes, não articuladas, ápice agudo, base cuneada, glabra em ambas as superfícies, margens incisoserreada; venação livre, nervuras furcadas, terminando nos dentes. Soros marginais, 2-4 $\times 0,6-1 \mathrm{~mm}, 1-5$ por pina; indúsio reniforme, membranáceo.

Material examinado: estufa do Orquidário, 11.V.1989, L. S. Sylvestre s.n. (RB 403115); 12.V.2004, S. L. S. Winter 93 (RB).

Adiantum formosum é uma espécie nativa, bastante comum na Austrália e de ocorrência rara na Nova Zelândia (Brownsey \& Smith-Dodsworth 2000). No Brasil é cultivada no JBRJ, na estufa do Orquidário em local sombreado na margem do córrego.

\section{Adiantum pectinatum Kunze ex Baker in} Hooker \& Baker, Syn. fil.: 120. 1867.

Fig. $3 \mathrm{e}$

Plantas terrestres. Caule curto a longoreptante, ca. $6 \mathrm{~mm}$ diâm., revestido por escamas lanceoladas, castanho-claras a castanhoescuras, ápice agudo a acuminado, margens dentadas, 2,5-5 × 0,5-1 mm. Frondes eretas a decumbentes; pecíolo 17-37 cm × 2,5-3 mm, robusto, cilíndrico, castanho-escuro a preto, pubescente-escamoso, escamas castanho-claras a avermelhadas, linear-subuladas, base ciliada, ápice filiforme, margens denteadas, tricomas articulados, castanho-avermelhados; lâmina 35-pinada, lanceolada, 30-34 × 20-40 cm, cartácea, verde-clara, com idioblastos; raque mais densamente pubescente-escamosa, escamas e tricomas semelhantes aos do pecíolo, castanho-escura a preta; pinas 4-5 pares, pecioluladas, oblanceoladas; pina apical conforme; pínulas dimidiadas, ápice redondo, base cuneada, inciso-dentada, glabras em ambas as faces, não articuladas com o peciólulo; venação livre, nervuras simples ou furcadas. Soros marginais, $1-2 \times 1-2 \mathrm{~mm}, 1-7$ por pínula; indúsio reniforme, membranáceo.

Material examinado: estufa do Orquidário, 11.V.1989, L. S. Sylvestre s.n. (RB 403102); 19.VIII.2003, F. R. Simões et al. 78 (RB); 17.V.2004, S. L. S. Winter 79 (RB); 15.VI.2005, S. L. S. Winter 244 (RB).
Adiantum pectinatum é uma espécie amplamente distribuída na América tropical, ocorrendo desde a Costa Rica até a Argentina. No Brasil, ocorre do estado de Rondônia à Santa Catarina. É encontrada em cultivo na estufa do Orquidário, em local seco e exposto ao sol.

9. Adiantum pentadactylon Langsd. \& Fisch., Ic. fil.: 22, tab. 25. 1810.

Fig. $3 \mathrm{f}$

Plantas terrestres. Caule curto-reptante, ca. $5 \mathrm{~mm}$ diâm., revestido por escamas castanho-claras a castanho-escuras, filiformes a lanceoladas, ápice agudo, margens inteiras a levemente crenadas, $1,5-2 \times 0,5-0,7 \mathrm{~mm}$. Frondes eretas a decumbentes; pecíolo 26$51 \mathrm{~cm} \times 2-3 \mathrm{~mm}$, anguloso, brilhante, castanhoescuro a preto, revestido na base por escamas semelhantes às do caule, glabro distalmente; lâmina pedada, 3-pinada, $20-37 \times 33-37,5 \mathrm{~cm}$, cartácea, verde-clara, com idioblastos; raque angulosa, deflexa, castanho-escura a preta, glabra; pinas 2-3 pares, pecioluladas; pínula trapeziformes, ápice agudo, base cuneada, com margens inciso-serreada, glabras em ambas as faces e glaucas abaxialmente, não articuladas ao peciólulo; venação livre, nervuras simples ou furcadas. Soros marginais, $2-5 \times 1-2 \mathrm{~mm}, 3-8$ soros por pínula; indúsio oblongo, membranáceo. Material examinado: estufa do Orquidário, 11.V.1989, L. S. Sylvestre s.n. (RB 403106);22.VIII.2003, F.R. Simões et al. 92 (RB); 15.V.2004, S. L. S. Winter78(RB).

Adiantum pentadactylon é uma espécie com distribuição geográfica restrita ao Brasil, ocorrendo de Minas Gerais ao Rio Grande do Sul (Prado \& Palacios-Rios 1998). É uma espécie que se encontra em cultivo na estufa do Orquidário, crescendo em local sombreado.

10. Adiantum raddianum $\mathrm{C}$. Presl, Tent. Pterid.: 158. 1836. Fig. $3 \mathrm{~g}$

Plantas terrestres ou rupícolas. Caule curtoreptante, 1-3 mm diâm, revestido por escamas lanceoladas, castanho-claras, ápice agudo e margens inteiras, 1,5-2×1-1,2 mm. Frondes eretas; pecíolo $7-30 \mathrm{~cm} \times 1,2-1,8 \mathrm{~mm}$, cilíndrico a anguloso, castanho-escuro a preto, superfície com pequenas projeções na base, revestido na base por escamas semelhantes a do caule; lâmina 3-4-pinada, 8-22 
×9-20 cm, cartácea a membranácea, verde-clara; raque deflexa, sulcada adaxialmente, castanhoescura a preta, glabra; pinas 4-9 pares, pecioluladas; pina apical conforme; pínula flabeladas, base cuneada, margens inteiras a incisas, denteadas, glabras em ambas as faces, não articuladas ao peciólulo; venação livre, nervuras simples ou furcadas, terminando entre os dentes na margem da lâmina. Soros marginais, $0,5-1,5 \times 0,5-1,3 \mathrm{~mm}, 1-16$ por pínula; indúsio reniforme, membranáceo.

Material examinado: estufa do Orquidário, 11.V.1989, L. S. Sylvestre s.n. (RB 403103); 7.VI.2004, S. L. S. Winter 162 (RB); 8.VIII.2004, S. L. S. Winter 172 (RB); Canteiro 9 B, 22.VIII.2003, F. R. Simões et al. 93 (RB).

Trata-se de uma espécie largamente cultivada em todo o mundo, sendo encontrada em toda a América tropical. No Brasil encontra-se amplamente distribuída, ocorrendo praticamente em todos os estados. Esta espécie é nativa e facilmente encontrada em locais sombreados do JBRJ, crescendo também na estufa do Orquidário e em canteiros, como saxícola ou rupícola.

11. Adiantum anceps Maxon \& C.V. Morton, Amer. Fern J. 24: 15. $1934 . \quad$ Fig. 1f

Plantas terrestres. Caule longo-reptante, 10-11 mm diâm., revestido por escamas filiformes a lanceoladas, castanho-claras, ápice afilado a acuminado, margens serreadas, 57,5 $\times 1-1,5 \mathrm{~mm}$. Frondes eretas a decumbentes; pecíolo 48-62 $\mathrm{cm} \times 4-5 \mathrm{~mm}$, cilíndrico abaxialmente e levemente sulcado adaxialmente, castanho a preto, brilhante, revestido na base por escamas semelhantes às do caule, glabro distalmente; lâmina 3-pinada, tripartida, trapezoidal, 45-54 × 30-35 cm, cartácea, verde-escura, com idioblastos na face adaxial; raque cilíndrica abaxialmente e levemente sulcada adaxialmente, castanho a preta, brilhante, glabra; pinas 3-4 pares, pecioluladas, ápice agudo; pina apical conforme; pínulas lanceoladas à deltóide-auriculadas, com aurícula voltada para a raquíola, ápice agudo, base cuneada, margens estéreis denteadas, articuladas com o peciólulo; venação livre, nervuras furcadas. Soros marginais, $0,5-0,8 \times$ 0,2-0,3 $\mathrm{mm}, 24-43$ por pínula; indúsios reniformes a oblongos, membranáceos.
Material examinado: estufa do Orquidário, 19.VIII.2003, F. R. Simões 71 (RB); 12.V.2004, S. L. S. Winter 90 (RB).

Possui distribuição restrita à América do Sul, sendo conhecida apenas para a Colômbia, Equador, Peru e Bolívia. No Brasil é encontrada apenas em cultivo. Planta cultivada na estufa do Orquidário, à sombra e em local bastante úmido.

12. Adiantum trapeziforme L., Sp. pl. 2: 1097. $1753 . \quad$ Fig. 1 d-e

Plantas terrestres. Caule longo-reptante, 2-5 mm diâm., revestido por escamas lanceoladas, castanho-escuras, ápice agudo, margens denticuladas, 0,7-1,5 ×0,2-0,5 mm. Frondes eretas a decumbentes; pecíolo 68-86 $\mathrm{cm} \times 4-5 \mathrm{~mm}$, cilíndrico abaxialmente e sulcado adaxialmente, castanho-escuro a preto, revestido na base por escamas semelhantes às do caule no sulco por escamas esparsas lanceoladas, ápice agudo, margens inteiras, 5-7 × 1-2 mm; lâmina 4-pinada, lanceolada, 43-60 × 30-50 cm, cartácea, verde-escura; raque cilíndrica abaxialmente e sulcada adaxialmente, castanho-escura, glabra, sem idioblastos; pina 3-5 pares, pecioluladas, ápice agudo; pina apical conforme; pínulas trapeziformes, lanceoladas, ápice agudo, base cuneada, margens inciso-dentadas; pínula apical lanceolada glabras em ambas as faces, articuladas ao peciólulo; venação livre, nervuras simples ou furcadas. Soros marginais, $2-5 \times$ 1-1,5 mm, 10-22 por pínula; indúsio oblongo, membranáceo.

Material examinado: estufa do Orquidário, 19.VIII.2003, F. R. Simões et al. 77(RB); 17.V.2004, S. L. S. Winter 80 (RB); 15.V.2004, S. L. S. Winter 245 (RB).

Esta espécie está distribuída em parte do México, Cuba, Jamaica, Antilhas, Trinidad, e possivelmente na Venezuela, sendo também muito cultivada nos EUA. No JBRJ é cultivada na estufa do Orquidário, à sombra e em local bastante úmido. Também ocorre na margem do córrego, junto com outras espécies de Adiantum.

13. Adiantum tenerum Sw., Prodr.: 135. 1788.

Fig. $21-\mathrm{m}$

Plantas terrestres, rupícolas ou saxícolas. Caule curto-reptante, 3-4 mm diâm., revestido por 
escamas filiformes a lanceoladas, ápice acuminado a agudo, margens ciliadas, $1,5-2,5 \times 0,2-0,5 \mathrm{~mm}$. Frondes eretas a decumbentes; pecíolo $20-40 \mathrm{~cm}$ $\times 1,5-2 \mathrm{~mm}$, cilíndrico, castanho-escuro a preto, brilhante, revestido na base por escamas semelhantes às do caule; lâmina 3-5-pinada, deltóide, $18-40 \times 10-25 \mathrm{~cm}$, cartácea, verde-clara; raque cilíndrica, castanho-escura a preta, glabra, sem idioblastos; pinas 4-5 pares, pecioluladas; pina apical conforme; pínulas cuneado-flabeladas a rômbicas, ápice arredondado, base cuneada, margens denticuladas, articuladas com o peciólulo, glabras em ambas as faces e glauca abaxialmente; venação livre, nervuras simples ou furcadas, terminando nos dentes junto à margem da lâmina. Soros marginais, $1-2 \times 0,5-0,7 \mathrm{~mm}, 5-14$ por pínula; indúsio oblongo, membranáceo.

Material examinado: estufa do Orquidário, 11.V.1989, L. S. Sylvestre s.n. (RB 403108, 403111); 13.II.2003, F. R. Simões \& C. M. Mynssen 6 (RB); 17.V.2004, S. L. S. Winter 54, 77, 85, 86 (RB); 7.VI.2004, S. L. S. Winter 157 (RB); Canteiro 9 B, 22.VIII.2003, F. R. Simões et al. 20 (RB).

Esta espécie é nativa e amplamente distribuída no norte da América do Sul (desde o México até a Venezuela, também no Caribe e Trinidad). No Brasil, aparece apenas como uma planta cultivada, com registro nos estados de Pernambuco, Paraíba, Rio de Janeiro e Rio Grande do Sul. Ocorre na estufa do Orquidário, à sombra e em local bastante úmido. Cresce também nos canteiros, como saxícola ou rupícola, exposta ou não ao sol.

\section{Adiantum tenerum Sw. cv 'fergunsonii'.}

Fig. $2 \mathrm{j}-\mathrm{k}$

Plantas terrestres, rupícolas ou saxícolas. Caule curto-reptante, 2,5-3 mm diâm., revestido por escamas lanceoladas, marginadas, ápice agudo, margem fimbriada, 1-1,5 ×0,7-1 mm. Fronde ereta; pecíolo 11-34,5 cm compr., cilíndrico não sulcado, marrom, revestido na base por escamas semelhantes às do caule; lâmina 4-pinada, lanceolada, 13-37×9-15 cm, cartácea, verde-claro, ápice agudo, base cuneada, com idioblastos na face adaxial; raque cilíndrica, castanho-nigrescentes, glabra; pina 4-5 pares, pecioluladas, ápice agudo, pina apical conforme; pínula deltóide-flabelada, ápice redondo, base cuneada, anádroma, margem dentada, articulada com peciólulo, pínulas sobrepostas, venação livre e furcada em direção aos dentes, glabra. Soros marginais, reniformeoblongos, $2-5 \times 1-1,2 \mathrm{~mm}, 9-18$ por pínula; indúsio reniforme-oblongo, membranáceo.

Material examinado: estufa do Orquidário, 15.V.2005, S. L. S. Winter 242 (RB); 8.VIII.2004, S. L. S. Winter 169 (RB).

Esta espécie está distribuída nas Américas, sendo descrita para o sul dos EUA, México, Colômbia e Venezuela. Ocorre na estufa do Orquidário, na sombra e em local bastante úmido, sendo terrícola ou rupícola, nas margens do córrego.

\section{Discussão}

O gênero Adiantum no arboreto do Jardim Botânico do Rio de Janeiro está representando por 13 espécies e um cultivar, o que corresponde a 17\% das pteridófitas (81 spp., dados não publicados) encontradas no arboreto.

As espécies Adiantum raddianum, A. tenerum e $A$. tenerum cv fergunsonii ocorrem como terrestres, rupícolas ou saxícolas, os demais táxons são essencialmente terrestres.

A grande maioria das espécies de Adiantum, cerca de 72\% (10 spp.), está restrita à estufa do Orquidário no JBRJ. Algumas espécies, 21\% (3 spp.), ocorrem tanto nas estufas quanto nos canteiros, como Adiantum tenerum, $A$. raddianum e A. latifolium. Apenas A. serratodentatum não foi observado no interior das estufas.

A análise do padrão de distribuição geográfica indicou que 12 espécies (86\%) são neotropicais, oito são nativas do Brasil, sendo Adiantum pentadactylon considerada endêmica. As espécies A. caudatum e A. formosum possuem distribuição na região Paleotropical (14\%).

Segundo o inventário elaborado por Sylvestre (1989), na coleção viva de pteridófitas do JBRJ o gênero Adiantum estava representado por 30 espécies. Considerando o atual levantamento, verifica-se que este número foi reduzido para menos de $50 \%$ dos táxons que existiam. As espécies Adiantum poiretii Wikstr. e A. farleyense T. Moore, por exemplo, listadas por Sylvestre (1989), possuem registros somente no Herbário RB. Essa perda ocorreu devido à 
falta de manutenção e de manejo adequado da coleção viva depositada na estufa do Orquidário. Esta estufa ficou desativada por cerca de 10 anos e atualmente foi reestruturada, mas priorizou-se a coleção de orquídeas.

\section{Agradecimentos}

Ao Instituto de Pesquisas Jardim Botânico do Rio de Janeiro e ao Programa Institucional de Bolsas de Iniciação Científica - PIBIC e ao Conselho Nacional de Desenvolvimento Científico e Tecnológico - CNPq, pela bolsa concedida à primeira autora.

\section{REFERÊNCIAS BIBLIOGRÁFICAS}

Alfaia, A. L. D.; Bottino, C. S.; Wenzel, M. S. M. T.; Rueda, M. M. M.; Gouveia, M. T. J; \& Saísse, M. V. 1998. Conhecendo nosso jardim: roteiro básico. Instituto de Pesquisas Jardim Botânico do Rio de Janeiro, Rio de Janeiro, 60p.

Brownsey, P. J. \& Smith-Dodsworth, J. C. 2000. New Zealand ferns and allied plants. $2^{\text {nd }}$ ed. David Bateman Ltd., Albany, 168p.

Lellinger, D. B. 2002. A modern multilingual glossary for taxonomic pteridology. Pteridologia 3A. American Fern Society, Inc., Washington, 264p.

Lellinger, D. B \& Prado, J. 2001. The group of Adiantum gracile in Brazil and environs. American Fern Journal 91(1): 1-8.

Mickel, J. T. \& Beitel, J. M. 1988. Pteridophyte flora of Oaxaca, Mexico. Memoirs of the New York Botanical Garden 46: 568.

Pichi-Sermolli, R. E. G. 1996. Authors of scientific names in Pteridophyta. Royal Botanic Gardens, Kew, 78p.

Prado, J. 2000. A new species of Adiantum (Pteridaceae) from Bahia, Brazil. Brittonia 52(2): 210-212.

2001. Adiantum giganteum (Pteridaceae), a new maidenhair fern from Amazônia, Brazil. Fern Gazette 16(5): 209-212.

2003. New Species in Adiantum from Brazil. American Fern Journal 93(2): 76-80.
2004. Criptógamos do Parque Estadual das Fontes do Ipiranga, São Paulo, SP. Pteridophyta: 17. Pteridaceae. Hoehnea 31(1): 39-49.

. 2005. Pteridaceae. In: Cavalcanti, T. B. \& Ramos, A. E. (ed.). Flora do Distrito Federal, Brasil. V. 4. Embrapa Recursos Genéticos e Biotecnologia, Brasília. Pp. 185-215.

\& Lellinger D. B. 2002. Adiantum argutum, an unrecognized species of the A. latifolium group. American Fern Journal 92(1): 23-29.

\& Palacios-Rios, M. 1998. Taxonomy and distribution of Adiantum trapeziforme and A. pentadactylon. American Fern Journal 88(4): 145-149.

\& Smith A. R. 2002. Novelties in Pteridaceae from South America. American Fern Journal 92(2): 105-111.

Proctor, G. R. 1989. Ferns of Puerto Rico and the Virgin Islands. Memoirs of the New York Botanical Garden 53: 1-389.

Scamman, E. 1960. The maidenhair ferns (Adiantum) of Costa Rica. Contributions from the Gray Herbarium of Harvard University 187: 3-22.

Smith, A. R. \& Prado, J. 2004. New species in Adiantum and Pteris (Pteridaceae) from the Andes. Brittonia 56(1): 82-88.

Sylvestre, L. S. 1989. Inventário da coleção de pteridófitas do arboreto do Jardim Botânico do Rio de Janeiro. Relatório encaminhado à Chefe da Divisão do Arboreto do Jardim Botânico do Rio de Janeiro.

Tryon, R. M. \& Kramer, K. U. 1990. Pteridaceae. In: Kramer, K. U. \& Green, P. S. (eds.). The families and genera of vascular plants. Pteridophytes and Gymnosperms. Vol. 1. Springer Verlag, New York. Pp. 230-256.

Tryon, R. M. \& Tryon A. F. 1982. Ferns and allied plants, with special reference to tropical America. Springer Verlag, New York, 857p.

Windisch, P. G. 1992. Pteridófitas da região norteocidental do estado de São Paulo: guia para estudo e excursões. $2^{\text {a }}$ ed.. Universidade Estadual Paulista, São José do Rio Preto, 110p.+ilus. 